\title{
Evaluation of the responses of institutions and actors to the 2015/2016 El Niño drought in the Komati catchment in Southern Africa: lessons to support future drought management
}

\author{
LS Sifundza'*, P van der Zaag ${ }^{1,2}$ and I Masih' \\ IIHE Delft Institute for Water Education, P O Box 3015, 2601 DA, Netherlands \\ ${ }^{2}$ Department of Water Resources, Delft University of Technology, PO Box 5048, 2600 DA, Netherlands
}

\begin{abstract}
Future climate projections for Southern Africa indicate an increase in the severity of droughts. Drought preparedness and management are important in such regions to minimise impacts on people and the environment. The aim of this study was to explore the responses of different institutions and actors to the 2015/2016 drought in the Komati catchment, and, consequently, what these experiences imply for drought management in the future. This was done through in-depth interviews with 30 key actors in the study area, including farmers, engineers, water managers and weather services personnel. Additionally, we examined data on precipitation, streamflows, reservoir levels, publications and communications in media, and minutes of the Komati Joint Operation Forum (KJOF) meetings. The results indicate that, whereas scientific tools for water resources management and drought forecasting exist in the catchment, the information generated using the tools was not sufficiently utilised in water (re) allocation decision making. This can be explained by the indifference of many stakeholders to early warning information, and by the preference of stakeholders to secure farm water supplies to minimize socio-economic losses in the short term. This resulted in late implementation of drought measures, when the drought had already started. Most of the measures implemented (i.e. water rationing and intensified monitoring) only helped partially in the crisis situation and did not tackle the root causes of vulnerability of the water users, especially for farmers. From the 2015/2016 drought we learnt that pro-active drought management could be supported through developing a drought management plan that is endorsed by all actors. More efforts are needed to improve how weather forecast information is packaged, communicated, deliberated and used by institutions (e.g. KJOF) and end-users (e.g. farmers). Moreover, this case study demonstrates that learning from past drought events is useful for improving evidence-based tools, policies and practices for drought management.
\end{abstract}

Keywords: 2015/2016 drought, drought management, experiential learning, Incomati river basin, Komati catchment

\section{INTRODUCTION}

Future climate projections for Southern Africa indicate an increase in drought frequency, intensity and severity, due to reduced precipitation and increased temperatures (Dai, 2013; Engelbrecht et al., 2015), which is expected to be exacerbated by growing anthropogenic pressures on water use. Most of the severe droughts in the region, for example in 1982/1983, 1991/1992 and 2015/2016, were El-Niño induced and have become a recurrent characteristic of the Southern African climate (Archer et al., 2017; Masih et al., 2014). The 2015/2016 drought event is on record as the worst El-Niño induced drought in the region in the past 35 years. It impacted heavily on rainfed and irrigated agriculture, water resources and the environment (Baudoin et al., 2017), which resulted in a cereal deficit of about 7.8 million tons in the 2015/2016 season, compared to the previous year, leaving $9 \%$ of the population (about 27 million people) food insecure in the Southern African region (SADC, 2016). The response to the 2015/2016 and preceding droughts in Southern Africa has been mainly reactive, with obvious measures such as providing food and water aid to affected people (Vogel et al., 2010). These reactive measures do not tackle the root cause of vulnerability of the

${ }^{*}$ Corresponding author., e-mail: lungysifundza@gmail.com Current affiliation: Department of Geography, Environmental Science and Planning, University of Eswatini, Private Bag 4, Kwaluseni M201, Eswatini Received 20 November 2018; accepted in revised form 3 October 2019 water users (Baudoin et al., 2017; De Stefano et al., 2015), neither do they contribute to reducing the risk of future drought events or add value to strategic drought planning and management. As a result, most countries continue to experience severe impacts due to drought. However, there is a potential for using drought experiences as an evaluation tool and input to strategic planning, which could help to improve drought policy, use of decision support tools and drought management practices in the future.

The call for countries to move from reactive drought responses to more proactive responses (Baudoin et al., 2017; Wilhite, 2011) has remained largely unanswered by governments, due to ineffective implementation of drought policies, a function of 'government priorities' other than the needs of the communities (Pradhan et al., 2017), lack of participation of local level authorities in the drought management planning and decision making process and the absence of collaborative institutional structures at national level (Vogel et al., 2010). Many researchers advocate for decentralized institutional arrangements that will not only deal with drought impacts but address the fundamental causes of vulnerability among water users and farmers (Agrawal, 2008; Baudoin et al., 2017). In addition, Andreu et al. (2009) indicate that drought management plans are often not effective in meeting water demands during drought because most countries rely on infrastructural solutions rather than systematic policies that include improved early warning systems and drought monitoring. According to Buchanan-Smith (2000), an effective 
early warning system is that which will intervene before the drought event to prevent major or severe impacts. Furthermore, the effectiveness and accuracy of early warning systems, together with the way in which the information is translated and delivered by the meteorologists to the users, continue to be a prime concern of end users and decision makers (Seibert et al., 2017; Siderius et al., 2018; Sunday et al., 2013).

Water resources planners argue that drought preparedness and management in semi-arid and arid areas should target water resources planning with great emphasis on drought mitigation (Andreu et al., 2009). This approach is thought to be a key step towards proactive responses to droughts, particularly by including drought preparedness plans as part of river basin management planning (Rossi and Castiglione, 2011). Moreover, developing drought preparedness plans and national drought policies seems an important step towards reducing the impact and risk of drought (Estrela and Vargas, 2012; Garrote et al., 2007; Wilhite, 2011). However, drought preparedness plans and policies are not an end in themselves for water planners. There is a need for an enabling institutional environment across different scales (e.g. from local level to government level), as well as political will among all actors to effectively implement the plans and policies to attain their objective of reducing vulnerability and risk to drought for people and the environment. (Wang et al., 2015).

Most studies on drought management in Southern Africa focus their analysis at the regional and national scale (e.g. Baudoin et al., 2017; Siderius et al., 2018; Vogel et al., 2010; Wilhite, 2000). This research analyses the local or community level where drought management plans and policies are implemented or practised within a particular institutional arrangement. Improved scientific knowledge and tools for drought management are often lacking in developing countries and, consequently, inadequate policies and adaptation strategies can be the outcome. The aim of this study is to analyse the responses to the 2015/2016 drought event in the Komati catchment in Southern Africa, and how the knowledge and experience gained by different actors could be utilized to improve future drought management. The study analyses the existing strengths and gaps in scientific tools used for drought management and policy formulation in the Komati catchment, aiming to contribute to better decision and policy making for drought-resilient water resources management. Thus, this study contributes to the body of knowledge on drought management and evaluates the performance of drought policies, plans, decision support tools and practices for drought management.

\section{METHODOLOGY}

\section{Study area}

The study was carried out in the Komati catchment, which is one of the six catchments in the Incomati basin in Southern Africa. Whereas the Incomati basin is shared by three countries: Eswatini (formerly Swaziland), South Africa and Mozambique, the Komati catchment is shared between Eswatini and South Africa. The catchment is characterized by a semi-arid climate with a mean annual rainfall of $800 \mathrm{~mm} /$ year, which is highly variable in space and time (Van der Zaag and Vaz, 2003). The main land and water use in the catchment is agriculture, which is mostly dominated by perennial crops (sugarcane and fruit trees) and forest plantations (Nkomo and Van der Zaag, 2004).

The catchment has a mean annual runoff of $1430 \mathrm{Mm}^{3} /$ year (JIBS, 2001). There are five significant dams in the Komati catchment constructed to deal with the increasing water demand for commercial agriculture in the region (Fig. 1, Table 1). The Nooitgedacht and Vygeboom Dams are located in the upper part of the Komati catchment (in the South African part), the Maguga Dam (Eswatini) and Driekoppies Dam (South Africa) in the lower part of the catchment, and the Sand River Dam is supplied through a canal from the Lower Komati River in Eswatini. This study focuses on the lower part of the catchment, downstream of Maguga and Driekoppies Dams. These two dams are managed by the Komati Basin

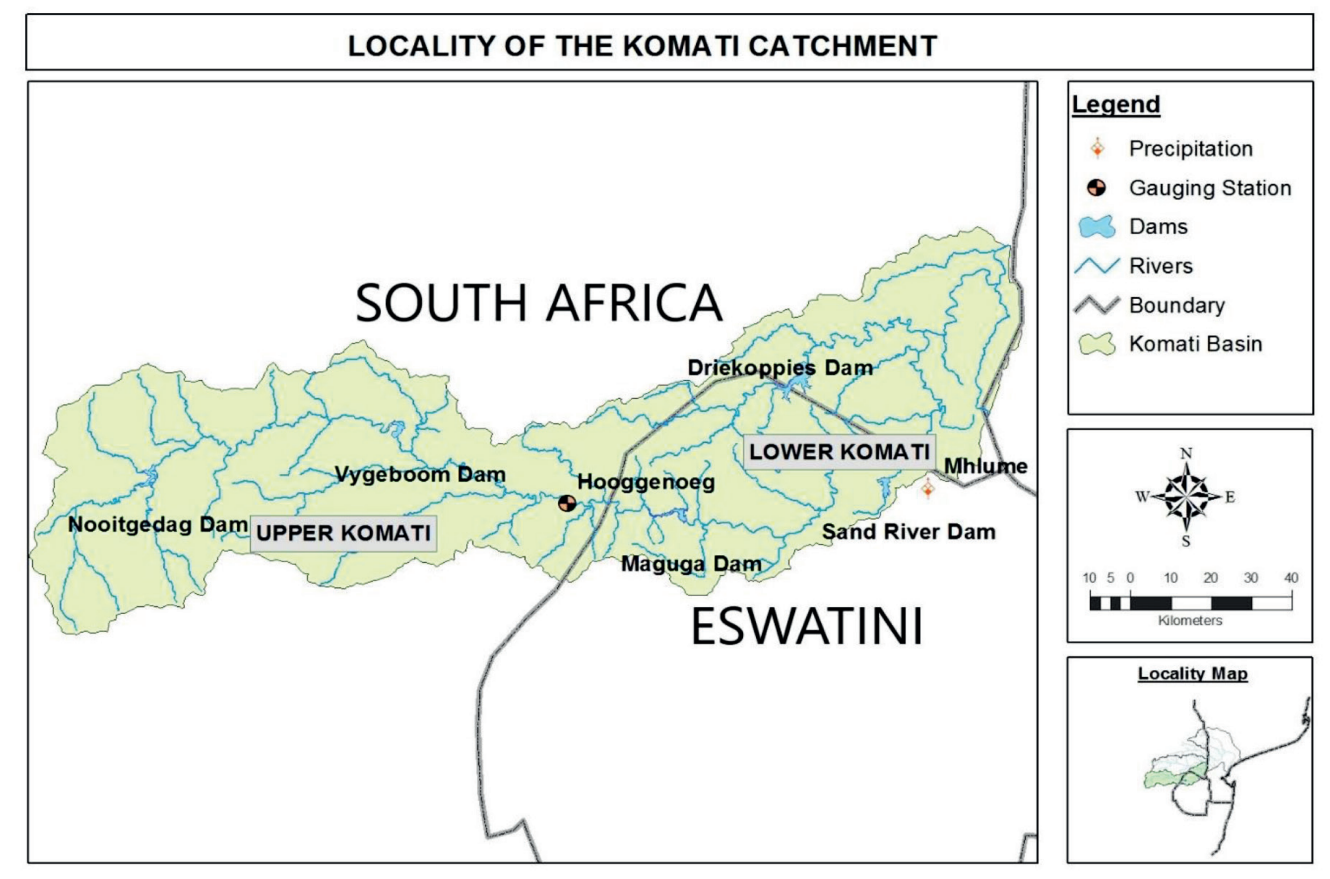

Figure 1. The Komati catchment 
Table 1. List of main reservoirs in the Komati catchment

\begin{tabular}{lccl}
\hline Dam & $\begin{array}{c}\text { Storage capacity } \\
\left(\mathbf{M m}^{3}\right)\end{array}$ & $\begin{array}{c}\text { Year } \\
\text { completed }\end{array}$ & Purpose of the dam \\
\hline Nooitgedacht & 78.2 & 1962 & Water for thermal power stations and bulk domestic water supply outside the basin \\
Vygeboom & 83.3 & 1971 & Water for thermal power stations \\
Maguga & 332.0 & 2002 & Water for irrigated agriculture, hydropower generation and domestic use \\
Driekoppies & 251.0 & 1998 & Water for irrigated agriculture and domestic use \\
Sand River & 49.0 & 1965 & Water for irrigation outside the basin \\
\hline Source: (DWAF, 2009) & & &
\end{tabular}

Water Authority (KOBWA), a bi-national organization that was established in 1993 as a result of the Development and Utilization of Water Resources of the Komati River Basin treaty. Table 2 indicates the main institutions involved in the planning and management of the Lower Komati.

\section{Institutional arrangement in the management of drought in the catchment}

The operation and management of the water resources in the Komati catchment is governed by policies, rules and regulations of the two countries (Eswatini and South Africa). The countries have different economic capacities, which suggests differences in the vulnerabilities of the two societies to drought. Although there is no written drought policy for the Komati catchment nor for the entire Incomati basin, the Komati Basin Water Authority (KOBWA) plays a major role in drought management through water management for Maguga and Driekoppies Dams on behalf of Eswatini and South Africa. KOBWA operates under rules developed by the Incomati System Operating Task Group (ISOTG), which is an institution comprising of representatives from Eswatini, South Africa and Mozambique. The rules gave competence to KOBWA to develop decision support tools, including water allocation and rationing models, used for the conjunctive operation of the Maguga and Driekoppies Dams.

Other important institutions which contribute to drought
Table 2. Institutions involved in water resource management in the lower Komati catchment, including the management of Maguga and Driekoppies Dams

\begin{tabular}{ll}
\hline Institutions & Country \\
\hline Tripartite Permanent Technical Committee & Eswatini, South Africa, \\
(TPTC) & Mozambique \\
Incomati System Operating Task Group & Eswatini, South Africa, \\
(ISOTG) & Mozambique \\
Joint Water Commission (JWC) & Eswatini, South Africa \\
Komati Joint Operations Forum (KJOF) & Eswatini, South Africa \\
Department of Water Affairs (DWA) & Eswatini \\
Department of Water and Sanitation (DWS) & South Africa \\
Inkomati-Usuthu Catchment Management & South Africa \\
Agency (IUCMA) & \\
Komati River Basin Authority (KRBA) & Eswatini \\
Komati-Lomati Irrigation Boards (IB) & South Africa \\
Mhlume Water & Eswatini \\
$\begin{array}{l}\text { Emandla Ekuphila Water User District } \\
\text { (EEWUD) }\end{array}$ & Eswatini \\
Disaster Management Agencies (DMA) & Eswatini, South Africa \\
\hline
\end{tabular}

management in the catchment are shown in Fig. 2 (see the Appendix for detailed roles of the institutions). These include Komati Joint Operation Forum (KJOF) and irrigation boards The disaster management agencies (DMAs) in both countries

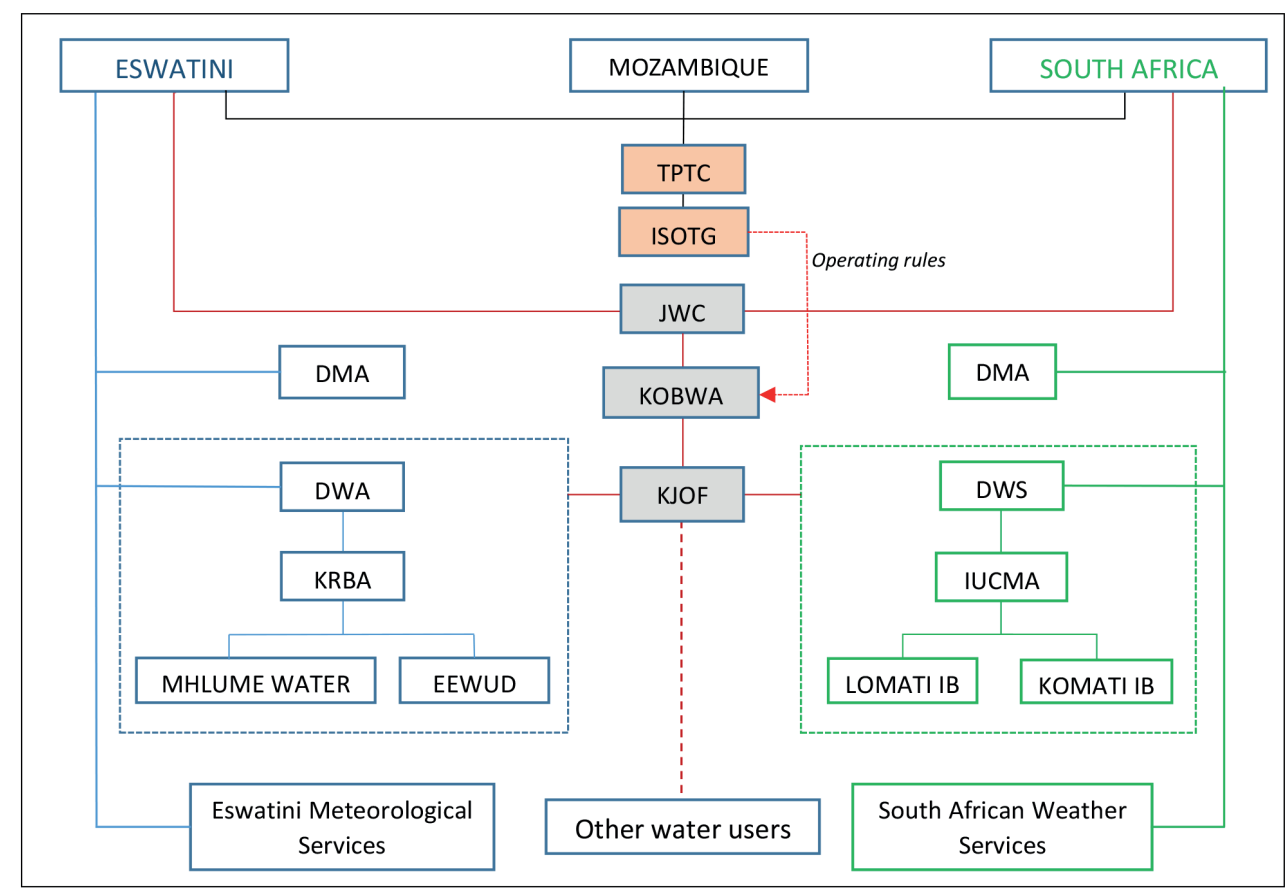

Figure 2. Schematic of the links between the institutions contributing to drought management in the Komati catchment (see Table 2 for definition of acronyms) 
facilitate the implementation of drought measures which are designed by the different sectors, such as agriculture and the water sector. The weather services in both countries provide weather and climate-related information.

\section{METHODS}

A qualitative research method was adopted to explore and evaluate the drought management practices of various actors in the Komati catchment. Data collection was done using in-depth semi-structured interviews with 30 actors in the study area, including water institutions, national representatives from the water departments in both Eswatini and South Africa, national disaster management agencies in both countries, weather services as well as smallholder and commercial farmers in both countries (Table 3 ). The field data were collected between November 2017 and January 2018. The purpose of the interviews was to get insight into how scientific knowledge, decision support tools and policies shaped responses to the 2015/2016 drought event for different actors and how the lessons learnt can be used to further future drought management. We used a topic list in which we examined the role of issues such as drought forecasting, monitoring, measures and practices, institutional and technical arrangements as well as postdrought assessment. Drought forecasting and monitoring acts as a guide to drought management planning and informs the responses by different actors and vice versa. These responses are facilitated or implemented as measures and practices under a particular institutional and technical arrangement. In turn, the measures and practices can shape or inform changes to existing institutional and technical arrangement. Post-event/drought assessment (evaluation) of the drought responses brings about experiential learning which could be embedded in future planning to improve drought management.

To complement information gathered from the interviews, we analysed data from secondary sources, including technical reports, online newspaper articles and official statements released during the drought, to cross-check the statements from the interview respondents. We also analysed in detail the minutes of the KJOF meetings held between October 2014 and December 2016. Moreover, we conducted a timeseries analysis of meteorological and hydrological data to characterize historical drought events and compared these with the 2015/2016 drought in terms of severity. The data from one precipitation station (Mhlume) and one gauging station (Hooggenoeg) were used to compute the Standardized Precipitation Index (SPI) and Standardized Runoff Index (SRI), respectively, using the SPI program. McKee et al. (1993) suggested a drought classification based on SPI values: mild drought (SPI: 0.0 to -0.99 ), moderate drought (SPI: -1.0 to -1.49 ), severe drought (SPI: -1.5 to -1.99 ), and extreme drought (SPI: less or equal to -2.0 ). These drought indicators were expressed in time scales of 3,6 and 12 months.

\section{RESULTS}

\section{Drought management practices: responses to the 2015/2016 drought}

There were a number of different drought mitigation and adaptation measures that were implemented during the 2015/2016 drought in the Komati catchment. These measures were implemented at national, provincial and local levels. The planning of the measures was done by the different actors in coordination with the countries' disaster management agencies. Since there is no specific drought policy or drought preparedness plan for the KOBWA water management area, the countries' sectorial plans were implemented at the local level. Nevertheless, rationing of water supplies during drought is a policy action stipulated in the ISOTG rules, which needs to be tailored to a certain drought situation. KOBWA, together with other transboundary institutions, was responsible for developing drought measures for Maguga and Driekoppies Dams to make sure water users (irrigation and domestic) in Eswatini and South Africa were served. The main drought mitigation measures implemented in the 2015/2016 drought, as well as other important drought response mechanisms, are summarised in the timeline presented in Fig. 3. In this section we first present the responses by institutions and thereafter by water users.

\section{Response by institutions}

Water rationing was the main drought adaptation measure that was implemented by the water management institutions in the 2015/2016 drought. Water rationing was implemented by KOBWA at allocation level, meaning that water users, on paper, were allocated less water than the treaty allocations, and other water user institutions such as the irrigation boards and water user districts, at distribution level, meaning that

Table 3. Overview of the interviewed institutions and actors in the study (see Table 2 for definition of acronyms)

\begin{tabular}{|c|c|c|c|c|c|c|}
\hline \multicolumn{2}{|c|}{ Government officials } & \multicolumn{2}{|c|}{ Water institutions } & \multicolumn{2}{|c|}{ Main water users } & \multirow[t]{2}{*}{ Total } \\
\hline Institution & $\begin{array}{c}\text { No. of } \\
\text { interviewees }\end{array}$ & Institution & $\begin{array}{c}\text { No. of } \\
\text { interviewees }\end{array}$ & Institution & $\begin{array}{c}\text { No. of } \\
\text { interviewees }\end{array}$ & \\
\hline DWA/DWS & 3 & KOBWA & 4 & $\begin{array}{l}\text { Smallholder } \\
\text { farmers }\end{array}$ & 8 & \\
\hline $\begin{array}{l}\text { Department of } \\
\text { Meteorology }\end{array}$ & 2 & Mhlume Water & 1 & $\begin{array}{l}\text { Commercial } \\
\text { farming }\end{array}$ & 2 & \\
\hline \multirow[t]{5}{*}{ JWC/TPTC } & 2 & iUCMA & 1 & Municipalities & 2 & \\
\hline & & EEWUD & 1 & & & \\
\hline & & irrigation boards & 1 & & & \\
\hline & & Komati River Basin Authority & 1 & & & \\
\hline & & DMA & 2 & & & \\
\hline Total & 7 & & 11 & & 12 & 30 \\
\hline
\end{tabular}


the institutions, on paper, were distributing less water than normally. In Fig. 3, only the water rationing implemented by KOBWA is indicated on the timeline. The use of the rationing model by KOBWA is a common practice and users are familiar with it: it is used twice a year under 'normal' conditions, which is in the beginning of the water year (which is April for KOBWA) and at the beginning of the rainy season (around November). However, during drought conditions the rationing model is used more frequently to determine when water use restrictions should be imposed, increased or reduced. In the water year 2015/2016, KOBWA imposed the first water use restriction in October 2015 (KJOF minutes dated 22 October 2015). The water use was restricted by $20 \%$ until the end of the water year (March 2016). It is worth noting that the water institutions which are decentralized from government, such as the Inkomati-Usuthu Catchment Management Agency (IUCMA) and KOBWA, were emphasizing the need to tighten the water use restrictions based on the rationing model results, to avoid stricter restrictions in the future. However, water user institutions, such as irrigation boards and Mhlume Water, as well as the Department of Water Affairs of Eswatini, were more concerned about the commercial farmers who had already planted their crops, because cutting irrigation would affect crop yields and thus their socio-economic situation. That is why water use restrictions were not tightened by KOBWA even though the dam levels were declining. Moreover, during the KJOF meeting of 28 January 2016, KOBWA kept on recommending to the forum that the water use restriction be increased beyond $20 \%$ due to the persisting drought conditions. However, the forum decided to maintain the $20 \%$ curtailment. This indicates a strong negotiation position of water users in KJOF. Water use rationing was increased to $40 \%$ only at the start of the $2016 / 2017$ water year, i.e., in April 2016, which is also the start of the dry season. Storage levels were at $30 \%$ of full capacity for Maguga Dam and $44 \%$ for Driekoppies Dam (Fig. 4) at that time. Restrictions were further increased to $80 \%$ in October 2016, which is normally the start of the rainy season. At that time storage levels of Maguga and Driekoppies Dams had dropped to 17\% and 25\%, respectively. Fortunately, the 2015/2016 drought did not turn out to be as long as the drought in the 1990s, as some good rains fell after October 2016, which resulted in increased river flows and thus rising storage levels in both Maguga and Driekoppies Dams. Consequently, water use rationing levels were reduced by KOBWA in January and April 2017.

\section{Use of early warning and communication}

The South African Weather Service (SAWS) and Eswatini Meteorological Services provide climate and weather information to guide water users and other actors. The Eswatini Meteorological Service and other actors in Eswatini rely on the information from the SAWS due to a lack of good climate forecasting technology in Eswatini. Therefore, the results presented in this study mainly focus on the operation of the SAWS. The SAWS use a multi-model system and climate drivers such as El Niño Southern Oscillation (ENSO), Indian Ocean Dipole (IOD) and Southern Annular Mode (SAM) for climate forecasting (SAWS, 2019). These global climatic indices are widely used in forecasting, following the basic assumption that they influence the global climate (Cai et al., 2011).

SAWS communicate weather and climate forecasts to public and private institutions (e.g. water and sanitation sector, agriculture, environment, etc.) through monthly weather advisories. The advisories are released to the stakeholders through the media (e.g. newspapers, television), workshops, meetings and online publications. The advisories indicated that the preceding hydrological year (2014/2015) was characterized by high temperatures and below-normal

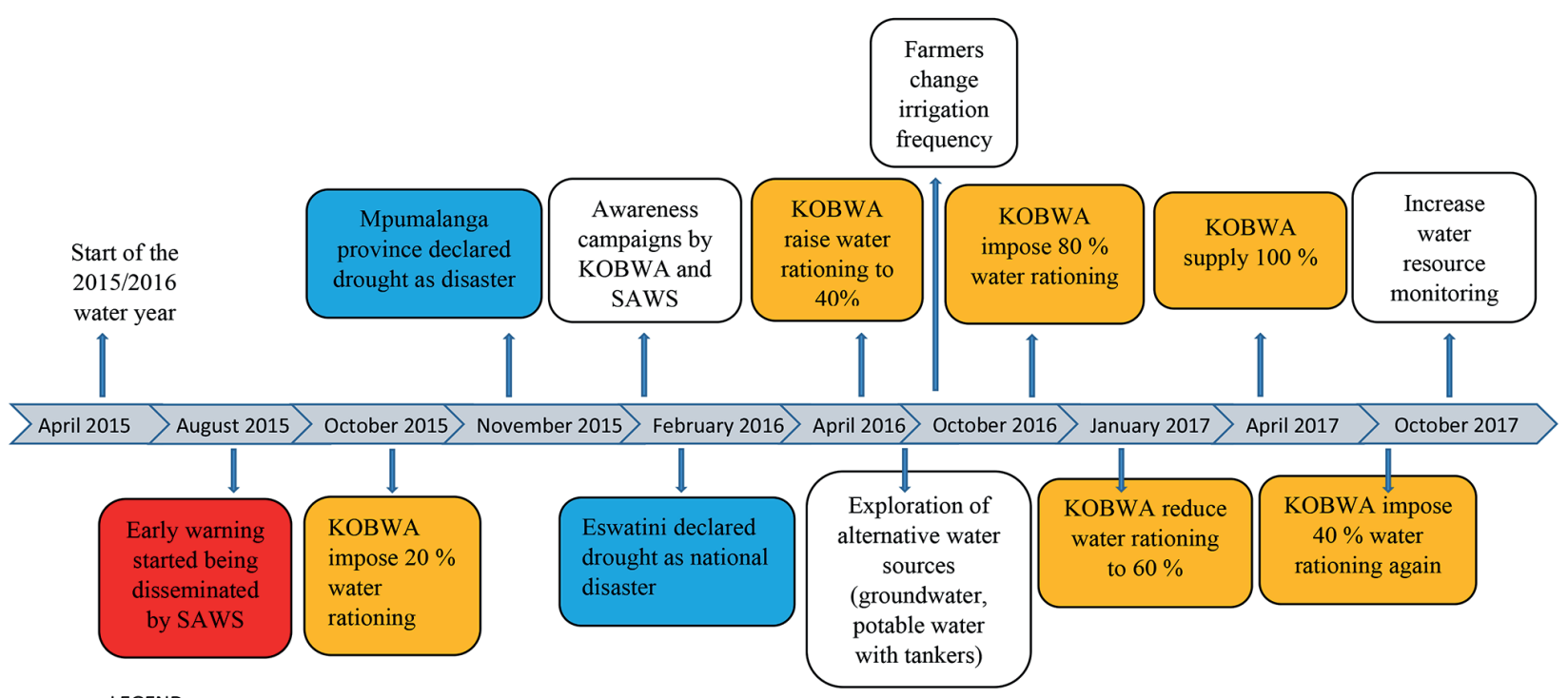

LEGEND

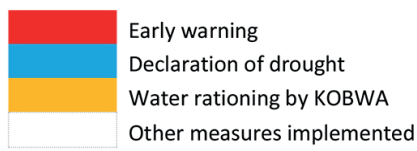

Figure 3. Timeline of some important responses to the $2015 / 2016$ drought event in the Komati catchment 


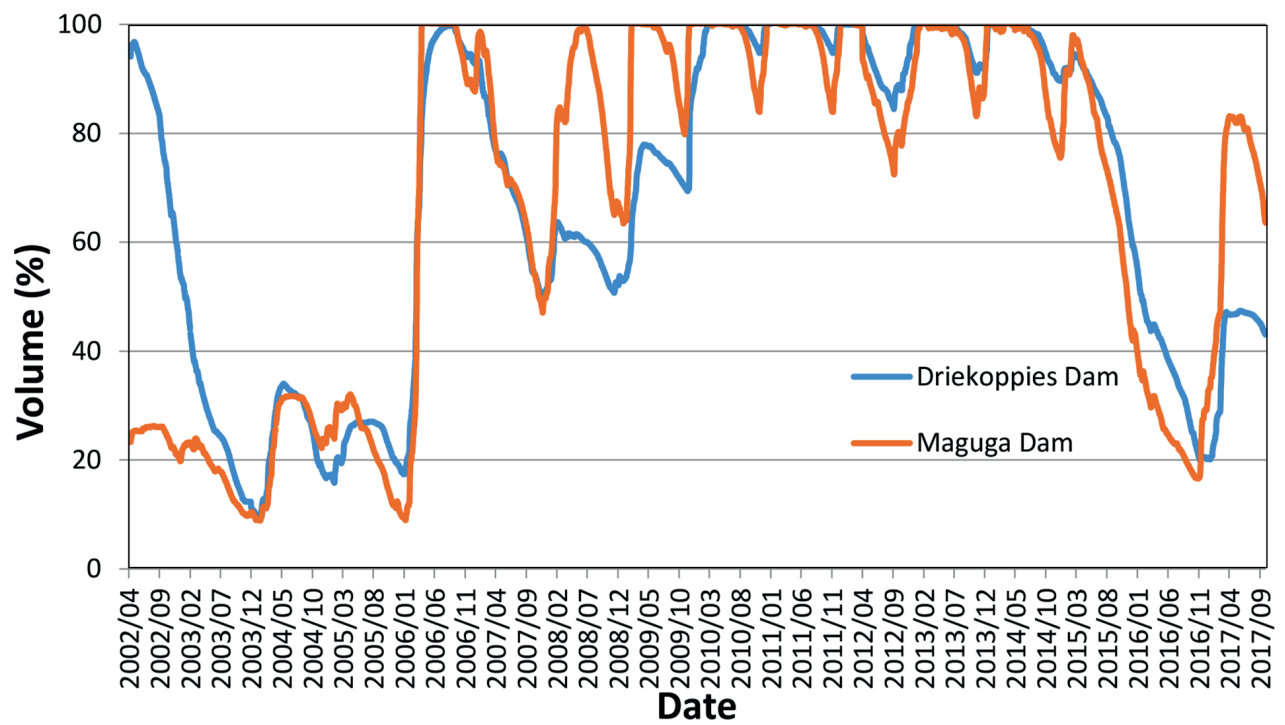

Figure 4. The volume of water stored in Maguga and Driekoppies dams, April 2002 - September 2017 (source: KOBWA, 2017)

rainfall. This was corroborated by rainfall data of Mhlume within the Komati catchment as noted in the following section on drought characterization and monitoring. However, the set of dynamic and statistical model predictions indicated a neutral ENSO condition throughout 2014 until early 2015, when the development of a weak El Niño was noticed. The strengthening of El Niño was noted in August 2015. Consequently, the high probability of extreme dry conditions was then predicted. Yet this happened relatively late. At this point, an official warning about the drought was released by the weather services. Consistent with these predictions, an extreme meteorological drought was observed during the rainy season 2015/2016, as noted by the SPI analysis; whereas the hydrological drought was only moderate (starting from May 2015), as noted in the following section on drought characterization and monitoring. Similarly, the inflows to Maguga and Driekoppies Dams had a declining trend as noted during the KJOF meetings held from March to August 2015. The minutes of these KJOF meetings make no mention of meteorological drought forecasts having been discussed. Even though during the 20 August 2015 meeting KOBWA had shown that its rationing model indicated that there was a need for water restrictions, the decision to implement was postponed because forum members did not come to an agreement about the water rationing. Also during that meeting it was decided to cancel the September meeting, as there was not much need for the Forum to meet.

\section{Enhanced monitoring and other actions}

In addition to rationing, the water management institutions in the catchment strengthened monitoring of the water resources. For example, the irrigation boards in South Africa strictly monitored their own members by actively using the telemetric system to monitor water abstraction as well as doing frequent site visits to check on compliance. Also, KOBWA intensified monitoring, particularly of groundwater levels throughout the catchment to evaluate groundwater-surface water interactions. These responses were coupled with awareness campaigns initiated by KOBWA, the municipalities as well as the weather services within the catchment; the campaigns targeted domestic water users, farmers and the wider public about the drought, its anticipated impacts and possible coping mechanisms. For example, KOBWA conducted awareness campaigns in about 10 communities in its area of operation, both in Eswatini and South Africa. The aim of the campaigns was to teach the public about water-saving technologies during the drought as a means to adapt to the drought situation (KOBWA, 2019).

As the water resources were depleting with the persisting drought and continuing water use by commercial farmers, the departments responsible for water in both countries started exploring alternative sources of water, such as groundwater. Both governments rehabilitated and drilled new boreholes for domestic water supply in municipalities in the catchment as well as supplied potable water with tankers through the disaster management agencies to communities that were most affected. In South Africa, new groundwater permits were issued for individuals who wanted to drill boreholes for irrigation purposes. However, some boreholes dried up due to declining groundwater levels. Since this was an emergency measure, the permits were issued without detailed groundwater mapping to determine the yields of aquifers. This highlights that scientific tools and processes were not adequately used during this drought emergency period, because there was not time available to apply them.

\section{Response by water users}

Different actors adapted to the drought differently, depending on their vulnerability and coping capacity. The commercial farming sectors, particularly sugarcane companies, like the Royal Swaziland Sugar Corporation (RSSC) in Eswatini, were better placed to deal with the drought than smallholder farmers. The commercial farmers, mainly sugarcane companies and citrus growers, adapted to both the drought and water rationing by KOBWA through adjusting their irrigation cycles, particularly by reducing the irrigation frequency, accepting the prospect of secure but lower yields. In the case of RSSC, the use of a decision support tool was key to making decisions on reducing the irrigation frequency. This model determined the critical water requirement at 
specific sugarcane growth stages and water was supplied just to keep the crop alive, to avoid having to replant the fields in the next season after the drought. Individual commercial farmers, especially in South Africa, owned small reservoirs to collect and store local runoff in addition to the water allocations from Maguga and Driekoppies Dams. Some were also drilling boreholes to supplement irrigation water. Smallholder farmers from both Eswatini and South Africa were prioritising the irrigated sugarcane fields by age and productivity; old and less productive fields were either irrigated less or abandoned altogether. Furthermore, smallholder farmers shifted the irrigation times from day to night when temperatures were lower to reduce evaporative losses. Other irrigated crops, such as maize, were not affected much but rainfed crops failed completely.

On the other hand, urban water supply on the Eswatini side, for Pigg's Peak town, was not affected as domestic water was given first priority. However, rural communities in Eswatini were very much affected by the drought because they depend for their household and agricultural supply on water drawn directly from the Komati River. As river levels were dropping significantly, they began competing with irrigating farmers for water. Even though on paper domestic water was to be given priority during the drought, as stipulated by the ISOTG rules, the Nkomanzi Municipality in South Africa was affected by the low river levels as its pumps for drawing water were directly installed in the river. This resulted in less water being treated thus less domestic water was supplied to the municipality. The municipality held awareness campaigns among the urban and rural communities together with KOBWA to promote water-saving technologies, and also drilled boreholes to enhance water supply for these households.

\section{Impact and challenges of the 2015/2016 drought}

For farmers, the major impact of the drought was on crop production; crop yields of both sugarcane in the commercial sector and cereals in the smallholder sector were affected. Compared to the long-term average (1970-2017), sugarcane yields were about $13 \%$ lower in the $2016 / 2017$ season, the lowest on record since 1970 (Fig. 5). Although the drought affected sugarcane yields, it did not have a negative effect on the sucrose content (Fig. 5).

The commercial farmers and the water user institutions (e.g. irrigation boards and water user districts) were not willing to adhere to water use rationing during the drought and this led to delays in the implementation of water use restrictions and was the major factor influencing tight water restrictions in the later stages of the drought. The strict water use restrictions of $60 \%$ were responded to by illegal water abstraction by commercial farmers beyond their allocations. Regardless of the implementation of water rationing and intensified monitoring, water users continued to abstract water. One of the interviewed commercial farmers boldly mentioned that 'we broke the water meters purposely to over-abstract without evidence.' Moreover, where there was evidence of 'over-abstraction', farmers were willing to pay the fine as, according to them, the benefit they got from the water was worth much more than the fine. This indicates that the fines charged were too low (e.g. about $0.004 \mathrm{USD} / \mathrm{m}^{3}$ ) to provide an incentive for farmers to use less.

The water abstractions by commercial farmers reduced the transboundary flow to Mozambique. The minimum transboundary flow to Mozambique, according to the Pigg's Peak Agreement signed in 1991 by the three riparian countries, is supposed to be $2 \mathrm{~m}^{3} / \mathrm{s}$ on average over 3 days, with $55 \%$ (1.1 $\left.\mathrm{m}^{3} / \mathrm{s}\right)$ coming from the Komati River and $45 \%\left(0.9 \mathrm{~m}^{3} / \mathrm{s}\right)$ from the Crocodile River (Van der Zaag and Vaz, 2003). Shortfalls of the agreed minimum transboundary flow to Mozambique started in October 2015 (KJOF minutes dated 19 November 2015). During the $2015 / 2016$ water year, the agreement was violated by actors in South Africa about $30 \%$ of the time with a total shortfall of $9.8 \mathrm{Mm}^{3} /$ year as reported in the annual report of KOBWA (2016). Things got even worse in the 2016/2017 water year, when KOBWA reported that the minimum flow to Mozambique was violated during 188 days ( $52 \%$ of time), with a shortfall of $12.1 \mathrm{Mm}^{3}$ (KOBWA, 2017).

To some extent, one of the challenges faced by governments was lack of finances and technological capacity to carry out planned drought mitigation and adaptation measures. For example, a groundwater inventory in Eswatini was planned to be undertaken before the 2015/2016 water year. However, the exercise was not carried out because of insufficient financial resources and scientific tools. This means that it was

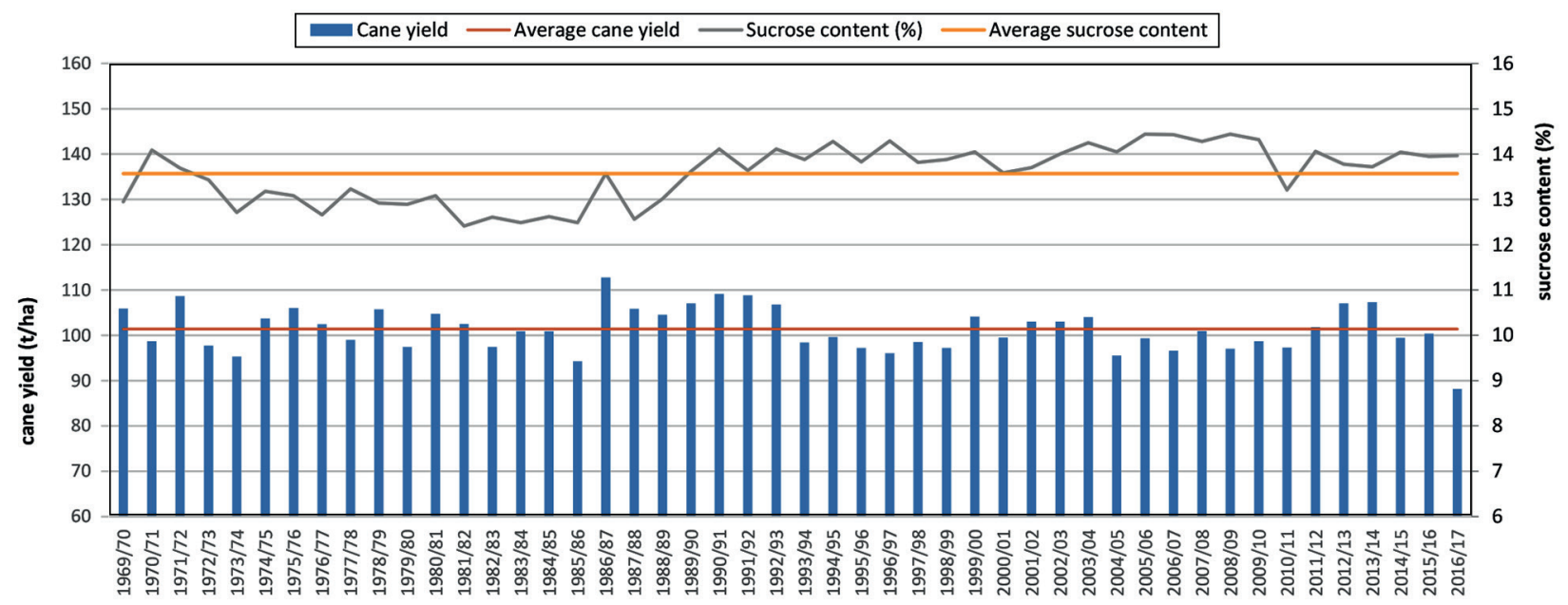

Figure 5. Historical average annual sugarcane yields in the lower Komati in Eswatini, and average sucrose content recorded by Mhlume sugar mills from sugarcane growers in the lower Komati catchment in Eswatini (adapted from Eswatini Sugar Association, 2017) 
not precisely known how much additional groundwater was available to supplement the dwindling surface water sources.

\section{Lessons learnt by different actors}

The severity and intensity of the 2015/2016 drought and experiences with its mitigation provide important lessons to different actors including the governments, farmers, and scientists, as well as decision and policy makers. The lessons learnt by scientists (e.g. water planners and managers) and decision makers ranged from the need to improve drought preparedness to implementation of drought adaptation measures as well as scientific tools used in drought management. The institutions in the catchment acknowledge that planning for drought is important to increase preparedness for future events. This includes developing drought preparedness plans by institutions from national to local level to ensure readiness up to the community level (water users). Moreover, a need for a coordinating drought task team was recognised by the several interviewed actors such as water planners, meteorologists and agriculturists, whereby representatives from different sectors such as agriculture, water and weather services can work together for the development of informed decisions in drought management. Whereas the DMAs might be doing that at national level, it has been suggested to introduce the drought task force at basin or catchment level.

Moreover, there is consensus on the need for water institutions in both South Africa and Eswatini to improve the technical expertise of farmers in water management and water use efficiency, e.g., through organising training events. Most farmers indicated that the government should provide financial assistance to support farmers to recover from the drought. In addition, some farmers realised the need to get insured against droughts to ensure security of their investments. Most actors within the catchment indicated the need for construction of more reservoirs to improve water supply. Since the frequency of extreme climate events (floods and droughts) is expected to increase in the future, most people are of the opinion that collecting and storing more water during flood events could be helpful during droughts.

The scientific tools used for drought forecasting by SAWS produce good results for climate forecasts and drought monitoring. However, SAWS learnt that the public or endusers of the weather (especially farmers) and climate forecast information have difficulty in correctly interpreting and using the information. For example, if the forecast indicates a $30 \%$ probability of rainfall, many farmers quickly conclude that they will receive rainfall. This has created a wrong perception among some users of climate forecasts.

Farmers using the sprinkler irrigation systems realised that this is not the best technology available and does not conserve water, therefore, is not drought-proof. More water-efficient systems were highly recommended by the farmers such as drip irrigation that can conserve more water and increase water productivity. However, the limitation is the financial resources associated with installing and maintaining a drip irrigation system. Alternatively, smallholder farmers suggested switching to annual crops (e.g. cereals and vegetables) rather than perennial crops such as
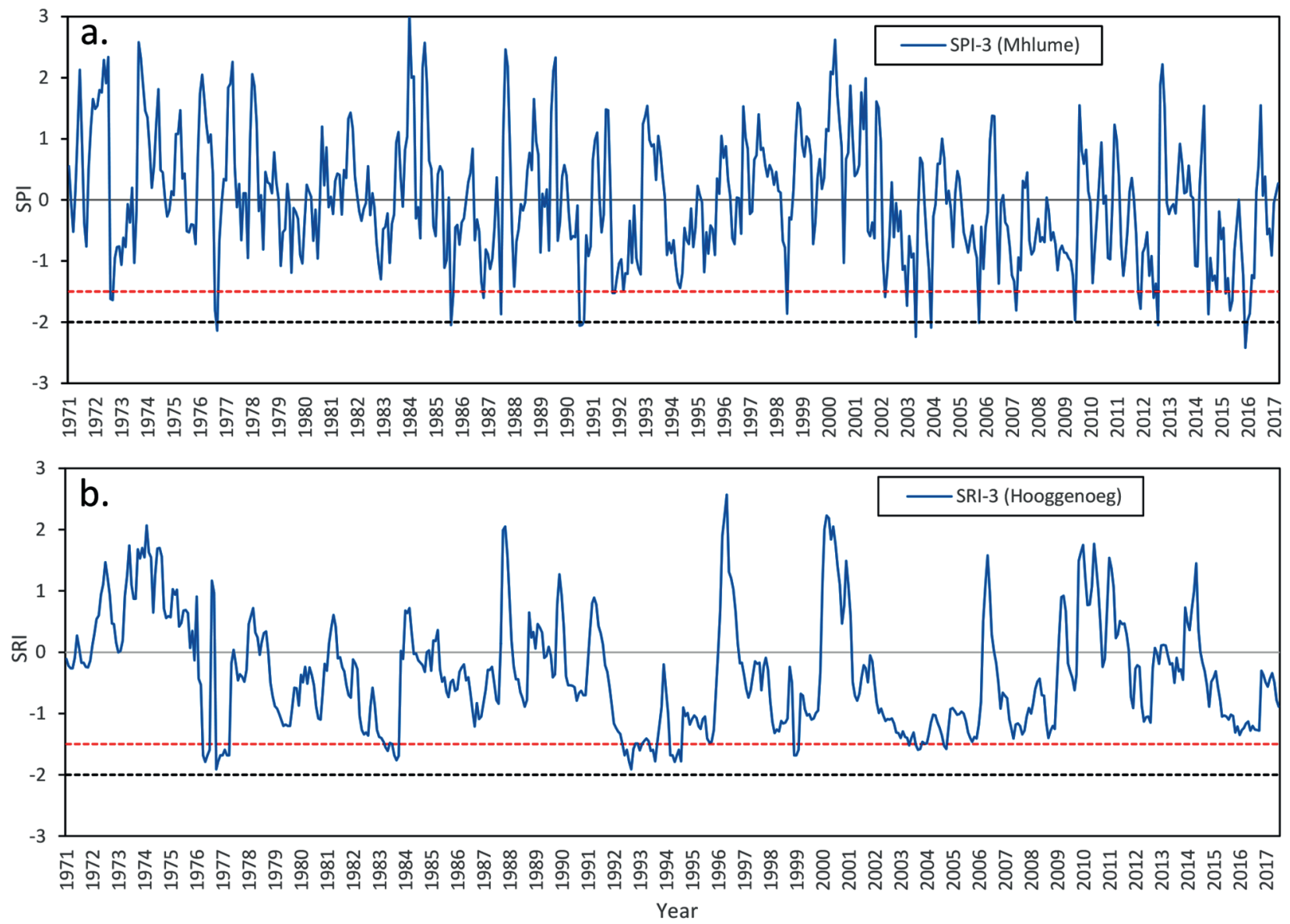

Figure 6. Time series of (a) meteorological drought indicator SPI-3 at Mhlume; and (b) hydrological drought indicator SRI-3 at Hooggenoeg 
sugarcane and fruit trees, which currently occupy more than $90 \%$ of the irrigated land in the catchment, but indicated this to be limited by market constraints.

\section{Drought characterization and monitoring}

Figure 6 presents the Standardized Precipitation Index (SPI) which we used to characterise meteorological drought, and the Standardized Runoff Index (SRI) used to characterize hydrological drought. Mishra and Singh (2010) define meteorological drought as the lack of precipitation in an area over a period of time and hydrological drought as the period where there is lack of surface water resources to adequately meet the water use in a water management system. Generally, both drought indicators capture the historic drought events, including 1982/1983, 1991/1995, 2003/2004 as well as the recent drought of 2015/2016. The dotted lines indicate the start of a severe drought $(-1.5$, red) and an extreme drought event ( -2 , black), following the drought classification by McKee et al. (1993). Figure 6 indicates that the 2015/2016 meteorological drought was the most severe since the 1980s. However, the drought of the early 1990s was longer than the 2015/2016 drought event. Consecutive droughts formed by mild and moderate droughts can be very devastating due to their total duration (Trambauer et al., 2014).

Figure 6 also shows that the meteorological droughts propagated into hydrological droughts, meaning that the lack of precipitation eventually resulted in declining surface and subsurface water resources. The SPI-3 values for March-June 2015 were in the range of -1.28 to -1.86 , indicating the onset of a severe to moderate meteorological drought. Most notably, the SPI-3 for the rainy season of 2015-2016 clearly depicted extreme drought as noted by the SPI values of below -1.5 for the period December 2015 to February 2016 (SPI: -2.42 in December and -1.86 in February). On the other hand, the SRI-3 dropped below -1.0 in May 2015, indicating the onset of a moderate hydrological drought. Later on, the SRI-3 estimates ranged between -1.0 and -1.3 from May 2015 until October 2016, indicating persistence of a moderate hydrological drought at Hooggenoeg hydrological station for about 17 months (see Appendix for results of SPI and SRI 6 and 12). These results show that even though an extreme meteorological drought is indicated at Mhlume in 2015/2016, this did not translate into an extreme hydrological drought but only a moderate drought at Hooggenoeg. This could be because of the difference in geographical location of the two stations as well as that the discharge is highly regulated due to the reservoirs upstream of the gauging station. Moreover, the hydrological drought was more persistent compared to the meteorological drought.

\section{DISCUSSION}

\section{Effectiveness of early warning system in drought management}

In theory, an effective early warning system is reliable, and communicated in understandable language to relevant stakeholders on time, to enable the stakeholders to plan for droughts and increase preparedness (De León et al., 2006; Kelman and Glantz, 2014; Wilhite, 2011). This can give end users of the information an opportunity to design systemic drought response measures in advance and reduce the risk of drought impacts. Results from this case study indicate that, despite the availability of good scientific knowledge and tools for climate forecasts, drought impacts were more severe compared to other previous droughts, mainly because competition for water resources has grown in the catchment. This observation agrees with Baudoin et al. (2017), who highlighted that there have been improvements in the drought forecasting capacity in South Africa but without a concomitant reduction of the impacts of droughts. This could be attributed to the insufficient use of the early warning information for planning by the actors (especially KJOF and farmers). For instance, the results of the rationing models were not sufficiently utilized to undertake timely decisions on water use curtailments by KJOF, which indicates a risk-taking attitude despite sound information on drought prevalence. Moreover, for some of the farmers who did use the information for planning purposes the information was communicated late. The insufficient use of available information and late communications may have contributed to unwanted reactive measures such as illegal abstractions and non-sustainable groundwater abstractions. Another noteworthy point is related to the reliability of the forecasts. The survey results indicated that many farmers do not have sufficient faith in the reliability of weather forecasts and do not use it when planning the irrigation season. This lack of trust may have developed because in the past when the weather services got the predictions wrong on several occasions, which could still happen due to uncertainties in the complexity of the climate system and limitations of the modelling procedures, despite remarkable scientific advances in the field of climate forecasting. For example, in 1997 the weather forecast in South Africa predicted a severe El Niño induced drought; however, the drought was not as severe as predicted. Farmers responded to the warnings by reducing purchase of agricultural inputs by $20 \%$. Such false alarms inform stakeholders' willingness to adopt drought-coping strategies or not (Wilhite et al., 2005). As expressed by Siderius et al. (2018), the accuracy and timeliness of the seasonal climate forecasts is still a main challenge for forecasters and those communicating the information to the different stakeholders and users.

Even though some farmers' perceptions of weather forecasts are negative, institutions such as KOBWA perceive the early warning information to be useful in planning. Use of this information for planning purposes is contested, particularly by those who do not trust the accuracy of the forecasts. This has contributed to delays in the implementation of mitigation measures such as water rationing, as was the case for the Lower Komati. This suggests that building confidence in the reliability of the climate forecasts is as important as the use of the scientific tools and technology. To build that confidence among planners and farmers, when communicated to endusers, climate forecasts needs to be fully translated to usable information that can be understood easily and used for planning, and should include information on the uncertainty range of the forecasts. Moreover, whereas the KJOF is the main forum where decisions on the use of water stored in Maguga and Driekoppies Dams and consequent releases are taken, the meteorological services were not involved in this forum and the meteorological drought forecasts were not explicitly deliberated in the meetings held during the 2015/2016 drought. Apart from the drought forecasts, real-time analysis of hydro-meteorological records (e.g. through SPI, SRI and other drought indicators) within the Komati catchment can provide a good scientific base for discussing suitable drought management actions. 


\section{Factors influencing effective drought management and experiential learning}

Many researchers call for decentralized water management institutions to improve the participation at local level (Agrawal, 2008; Vogel et al., 2010; Wilhite et al., 2014). In the Komati catchment, particularly the KOBWA management area, a participatory approach was noted to be practised. For example, KJOF consists of the representatives at national level (e.g. Eswatini Department of Water Affairs, DWA) as well as local level (water users such as irrigation boards). This forum usually holds monthly meetings to discuss issues of water management for the Maguga and Driekoppies Dams. Moreover, the use of scientific tools (e.g. hydrological models) by KOBWA to inform decision making for the two dams, such as water allocation and water rationing, was seen to be useful, especially during drought conditions. For example, although water rationing decisions were very difficult to make, the information generated by modelling tools was still instrumental in the discussions of KJOF and in the ultimate decisions taken on timing and amount of water use curtailments.

However, it was noted that most of the drought management strategies were implemented when the drought had already started and impacts had been felt. The response to the drought was thus reactive rather than proactive. Despite the well-structured institutional arrangements in the catchment, drought management strategies implemented in the 2015/2016 drought did not reduce the vulnerability of water users (especially farmers in the Lower Komati and further downstream users in Mozambique) to drought. Suggested measures such as construction of more reservoirs may not be a real solution as the water resources in the basin are already heavily utilised, with quite a high storage to runoff ratio (total storage of the existing significant reservoirs in the Komati catchment is $793 \mathrm{Mm}^{3}$ while annual runoff is about $1430 \mathrm{Mm}^{3} /$ year, giving a storage to runoff ratio of 0.55 ). The absence of a drought policy in the catchment as well as the lack of drought preparedness plans hinders the reduction of vulnerability of the water users. Moreover, the lower Komati catchment is highly dominated by perennial crops such as fruit trees and sugarcane, the latter being a high-water-demand crop, with an irrigated area that is still increasing. The dominance of perennial crops in the Komati catchment strongly reduces the ability to adaptively respond to a predicted drought. So, reducing the irrigated area or changing to seasonal and/or less water-demanding crops could reduce the vulnerability of the farmers. Promoting self-reliance among water users, especially farmers, can increase the coping capacity within society and thus reduce the risk of high impacts of future drought events (Iglesias et al., 2009); for example, through using water-efficient irrigation systems such as drip irrigation as well as making use of drought-resistant crop varieties and diversifying food sources (O'Farrell et al., 2009). The recommendations related to more efficient water use (e.g. adoption of drip irrigation) could contribute to reducing the drought impact to some extent if coupled with adequate institutional arrangements to limit the expansion of irrigation area. This research indicates the need for a cautious approach to avoid falling into the so-called 'efficiency paradox', because the higher efficiency rarely reduces water consumption (Grafton et al. 2018). For example, the farmers may decide to expand irrigated area to utilize the water saved through adoption of water-efficient technologies, which in turn may induce even more water consumption (e.g. Ahmad et al., 2014; Grafton et al. 2018).
Furthermore, it is often argued that effective management of drought risk might require additional technological, financial and human resources (Vogel et al., 2010; Baudoin et al., 2017). KOBWA is a relatively well-resourced institution in terms of scientific tools but use of the results from these technologies is not as effective as it could be, which was shown by the fact that water rationing was implemented late even though models had indicated otherwise. This suggests that not only are resources important in drought management but buy-in of the actors as well as political will are needed to efficiently implement drought measures. Post-assessment of the drought responses after every drought episode can greatly improve drought management through 'adaptive learning' (De Stefano et al., 2015).

\section{CONCLUSIONS}

This case study shows that scientific tools and coordinated monitoring and evaluation of drought management, in spite of their widely acclaimed potential for use in water resources planning and management, only partially inform decisions of water actors to start restricting water use. Despite the presence of scientific tools (e.g. models for climate forecast from SAWS and hydrological models within KOBWA) and institutional arrangements that allow stakeholder participation, drought management in the 2015/2016 drought was mainly based on reactive measures. The measures implemented partially helped in minimizing the damage for the water users but did not tackle the root cause of vulnerability of the water users, especially farmers. The use of scientific tools and knowledge during drought events was not fully translated to effective implementation of the decision support systems, as actors delayed acting on predictions or implementing drought measures. Therefore, developing drought preparedness plans by the water institutions can improve the coordination of the drought management practices, i.e., knowing what to do before, during and after a drought event. Moreover, timely decisionmaking during drought events can be supported by improved reliability and understanding of the model predictions (e.g. climate forecast and water resources availability and demands). Additionally, timely enactment of drought declaration protocols, and enhanced institutional collaboration, as well as adopting well-phased strategies to mitigate impacts (e.g. changes in cropping pattern and intensities), could support drought management in heavily committed catchments such as the Komati.

Although there seemed to be a great number of lessons learnt in 2015/2016 by the actors in the Komati catchment, the lessons remain fragmented or localised at sectorial or even individual level. Therefore, coordinated monitoring and evaluation of these lessons and experiences between the different sectors is needed to successfully use them in future drought events. In this context, the relevance of a drought task team has been suggested, whereby representatives from different sectors, including agriculture, water and weather services, coordinate activities at basin or catchment level during impending droughts. This case study thus demonstrates that learning from past drought management experiences could be very useful to further improve scientific tools, policies and practices for drought management.

\section{ACKNOWLEDGEMENTS}

This paper was based on an MSc study by the first author 
conducted at IHE Delft. The first author received a scholarship from Rotary International, which is gratefully acknowledged. The authors thank the Komati Basin Water Authority (KOBWA), for the assistance during field work. We are thankful to the interviewed stakeholders for providing data and information, including representatives from water institutions and government as well as water users from both Eswatini and South Africa.

\section{REFERENCES}

AGRAWAL A (2008) The role of local institutions in adaptation to climate change. Paper prepared for the Social Dimensions of Climate Change, Social Development Department, The World Bank, 5-6 March 2008. Washington DC. https://doi.org/10.1596/28274

ANDREU J, FERRER-POLO J, PÉREZ M and SOLERA A (2009) Decision support system for drought planning and management in the Jucar river basin, Spain. In: Proceedings of the 18th World IMACS/MODSIM Congress, 13-17 July 2009, Cairns, Australia.

ARCHER ERM, LANDMAN WA, TADROSS MA, MALHERBE J, WEEPENER H, MALULEKE P and MARUMBWA FM (2017) Understanding the evolution of the 2014-2016 summer rainfall seasons in southern Africa: Key lessons. Clim. Risk Manage. 16 22-28. https://doi.org/10.1016/j.crm.2017.03.006

BAUDOIN MA, VOGEL C, NORTJE K and NAIK M (2017) Living with drought in South Africa: lessons learnt from the recent El Niño drought period. Int. J. Disaster Risk Reduction 23 128-137. https://doi.org/10.1016/j.ijdrr.2017.05.005

BUCHANAN-SMITH M (2000) Role of early warning systems in decision-making processes. Paper presented in: The expert group meeting on early warning systems for drought preparedness and drought management, 5-7 September 2000. Lisbon, Portugal.

CAI W, SULLIVAN A and COWAN T (2011) Interactions of ENSO, the IOD, and the SAM in CMIP3 models. J. Clim. 24 (6) 1688-1704. https://doi.org/10.1175/2010JCLI3744.1

DAI A (2013) Increasing drought under global warming in observations and models. Nat. Clim. Change 3 (1) 52-58. https:// doi.org/10.1038/nclimate1633

DE LEÓN JCV, BOGARDI J, DANNENMANN S and BASHER $\mathrm{R}$ (2006) Early warning systems in the context of disaster risk management. Entwicklung Ländlicher Raum 2 23-25.

DE STEFANO L, URQUIJO J, KAMPRAGKOU E and ASSIMACOPOULOS D (2015) Lessons learnt from the analysis of past drought management practices in selected European regions: experience to guide future policies. Eur. Water 49 107-117.

DWAF (Department of Water Affairs and Forestry, South Africa) (2009) Inkomati Water Availability Assessment - Hydrology Report for the Komati River Catchment. Report PWMA 05/X22/00/1508. DWAF, Pretoria.

ENGELBRECHT F, ADEGOKE J, BOPAPE MJ, NAIDOO M, GARLAND R, THATCHER M, MCGREGOR J, KATZFEY J, WERNER M, ICHOKU C and co-authors (2015) Projections of rapidly rising surface temperatures over Africa under low mitigation. Environ. Res. Lett. 10 (8) 085004. https://doi. org/10.1088/1748-9326/10/8/085004

ESTRELA T and VARGAS E (2012) Drought management plans in the European Union. The case of Spain. Water Resour. Manage. 26 (6) 1537-1553. https://doi.org/10.1007/s11269-011-9971-2

ESWATINI SUGAR ASSOCIATION (2017) Crop statistics report 2016/2017. Technical services, Simunye, Eswatini.

GARROTE L, MARTIN-CARRASCO F, FLORES-MONTOYA F and IGLESIAS A (2007) Linking drought indicators to policy actions in the Tagus basin drought management plan. Water Resour. Manage. 21 (5) 873-882. https://doi.org/10.1007/s11269-006-9086-3

GRAFTON RQ, WILLIAMS J, PERRY CJ, MOLLE F, RINGLER C, STEDUTO P, UDALL B, WHEELER SA, WANG Y and co-authors (2018) The paradox of irrigation efficiency. Science 361 (6404) 748-750. https://doi.org/10.1126/science.aat9314

IGLESIAS A, MONEO M and QUIROGA S (2009) Methods for evaluating social vulnerability to drought. In: Iglesias A,
Cancelliere A, Wilhite DA, Garrote L and Cubillo F (eds) Coping with Drought Risk in Agriculture and Water Supply Systems. Advances in Natural and Technological Hazards Research, vol 26. Springer, Dordrecht. https://doi.org/10.1007/978-1-4020-9045-5

JIBS (2001) Joint Inkomati Basin Study Phase 2. Consultec in association with BKS Acres. Final Draft, April 2001.

KELMAN I and GLANTZ MH (2014) Early Warning Systems Defined. In: SINGH A, ZOMMERS Z (eds) Reducing Disaster: Early Warning Systems For Climate Change. Springer, Dordrecht. https:// doi.org/10.1007/978-94-017-8598-3_5

KOBWA (2016) Annual report 2015/2016. URL: http://www.kobwa. co.za/images/Annual\%20Report\%202016.pdf (Accessed 16 September 2019).

KOBWA (2017) Annual report 2016/2017. URL: http://www.kobwa. co.za/images/Annual\%20Report\%202017.pdf (Accessed 16 September 2019).

KOBWA (2019) KOBWA pilots community educators program in South Africa. URL: http://www.kobwa.co.za/index.php/mediacentre/awareness-campaigns (Accessed 16 September 2019).

MASIH I and GIORDANO M (2014) Constraints and opportunities for water savings and increasing productivity through Resource Conservation Technologies in Pakistan. Agric. Ecosyst. Environ. 187 106-115. https://doi.org/10.1016/j.agee.2013.07.003

MASIH I, MASKEY S, MUSSÁ F and TRAMBAUER P (2014) A review of droughts on the African continent: a geospatial and longterm perspective. Hydrol. Earth Syst. Sci. 18 (9) 3635. https://doi. org/10.5194/hess-18-3635-2014

MCKEE TB, DOESKEN NJ and KLEIST J (1993) The relationship of drought frequency and duration to time scales. In: Proceedings of the $8^{\text {th }}$ Conference on Applied Climatology, 17-22 January 1993, Anaheim, California.

MISHRA AK and SINGH VP (2010) A review of drought concepts. J Hydrol. 391 (1-2) 202-216. https://doi.org/10.1016/j. jhydrol.2010.07.012

NKOMO S and VAN DER ZAAG P (2004) Equitable water allocation in a heavily committed international catchment area: the case of the Komati Catchment. Phys. Chem. Earth A/B/C 29 (15-18) 1309-1317. https://doi.org/10.1016/j.pce.2004.09.022

O'FARRELL PJ, ANDERSON PML, MILTON SJ and DEAN WRJ (2009) Human response and adaptation to drought in the arid zone: lessons from southern Africa. S. Afr. J. Sci. 105 (1-2) 34-39. https://doi.org/10.4102/sajs.v105i1/2.36

PRADHAN NS, FU Y, ZHANG L and YANG Y (2017) Farmers' perception of effective drought policy implementation: A case study of 2009-2010 drought in Yunnan province, China. Land Use Polic. 67 48-56. https://doi.org/10.1016/j.landusepol.2017.04.051

ROSSI G and CASTIGLIONE L (2011) Towards guidelines for drought preparedness and mitigation planning within EU water policy. Eur. Water 36 37-51.

SADC (Southern African Development Community) (2016) Regional Situation Update El Niño-Induced drought. Issue 02: 12 September 2016.

SAWS (South African Weather Service) (2019) Long range forecast Global Climate Models. URL: http://www.weathersa.co.za/home/ longrangeforecast (last accessed 16 September 2019)

SEIBERT M, MERZ B and APEL H (2017) Seasonal forecasting of hydrological drought in the Limpopo Basin: a comparison of statistical methods. Hydrol. Earth Syst. Sci. 21 (3) 1611. https://doi. org/10.5194/hess-21-1611-2017

SIDERIUS C, GANNON K, NDIYOI M, OPERE A, BATISANI N, OLAGO D, PARDOE J and CONWAY D (2018) Hydrological response and complex impact pathways of the 2015/2016 El Niño in Eastern and Southern Africa. Earth's Future 6 (1) 2-22. https://doi. org/10.1002/2017EF000680

SUNDAY R, WERNER M, MASIH I and VAN DER ZAAG P (2013) Identifying needs for streamflow forecasting in the Incomati basin, Southern Africa. In: Proceedings of the EGU General Assembly Conference, 07-12 April 2013. Vienna, Austria.

TRAMBAUER P, MASKEY S, WERNER M, PAPPENBERGER F, VAN BEEK L, and UHLENBROOK S (2014) Identification and simulation of space-time variability of past hydrological drought events in the Limpopo River basin, southern Africa. 
Hydrol. Earth Syst. Sci. 18 (8) 292-2942. https://doi.org/10.5194/ hess-18-2925-2014

VAN DER ZAAG P and VAZ AC (2003) Sharing the Incomati waters: cooperation and competition in the balance. Water Polic. 5 (4) 349-368. https://doi.org/10.2166/wp.2003.0021

VOGEL C, KOCH I and VAN ZYL K (2010) "A persistent truth"-reflections on drought risk management in Southern Africa. Weather Clim. Soc. 2 (1) 9-22. https://doi. org/10.1175/2009WCAS1017.1

WANG J, YANG Y, HUANG J and CHEN K (2015) Information provision, policy support, and farmers' adaptive responses against drought: An empirical study in the North China Plain. Ecol. Model. 318 275-282. https://doi.org/10.1016/j.ecolmodel.2014.12.013 WILHITE DA (2000) Drought preparedness and response in the context of Sub-Saharan Africa. J. Contingencies Crisis Manage. 8 (2) 81-92. https://doi.org/10.1111/1468-5973.00127

WILHITE DA (2011) Breaking the hydro-illogical cycle: progress or status quo for drought management in the United States. Eur. Water 34 5-18.

WILHITE DA, BOTTERILL L and MONNIK K (2005) National drought policy: lessons learned from Australia, South Africa, and the United States. In: Wilhite DA (ed.) Drought and Water Crises: Science, Technology and Management Issues. CRC Press, Boca Raton. 137-172. https://doi.org/10.1201/9781420028386.ch6

WILHITE DA, SIVAKUMAR MV and PULWARTY R (2014) Managing drought risk in a changing climate: The role of national drought policy. Weather Clim. Extremes 3 4-13. https://doi. org/10.1016/j.wace.2014.01.002

\section{APPENDIX}

\section{Role of the institutions in the KOBWA management area}

Since the Komati catchment is transboundary, there are a number of agreements that govern water development and management in the catchment as well as the Incomati basin as a whole. The Tripartite Permanent Technical Committee (TPTC) provides advice on all technical matters regarding the sharing of rivers of common interest. This committee is composed of three representatives from each of the riparian countries. The committees' functions include, among others, to recommend any measures to be undertaken to reduce short-term problems regarding water shortages in rivers of common interest during drought periods. The establishment of the committee was followed by the Pigg's Peak Agreement of 1991 on the development of the Komati River Basin Project between South Africa and Eswatini. Mozambique is part of the agreement because one of the interim measures which came about as a result of the agreement was that the Komati and Crocodile catchments should maintain a cross-border release of $2 \mathrm{~m}^{3} / \mathrm{s}$ averaged over a cycle of 3 days to meet the water needs in the reach from Ressano Garcia in Mozambique.

In the Komati catchment, two bilateral treaties were signed between Eswatini and South Africa in 1992. One treaty is on the establishment and functioning of the Joint Water Commission and the other treaty on the Development and Utilization of Water Resources of the Komati River Basin. The latter treaty led to the establishment of KOBWA which was mandated to implement Phase 1 of the Komati River Basin Development Project. Phase 1 comprised the construction of the Driekoppies and Maguga Dams which were completed in 1998 and 2002, respectively.

Institutionally, water management in South Africa and Eswatini is carried out at various levels, from policy to management and operational levels. In Eswatini, water management is executed by the National Water Authority, the River Basin Authorities and lower level institutions. The Komati River Basin Authority is tasked with the role of managing the released water for users in the Komati catchment. However, the authority is still in its infancy stage; hence, most of its activities are currently done by the Eswatini Department of Water Affairs (DWA). Lower level institutions for operations on the ground include Emandla Ekuphila Water User District (EEWUD) for small-scale farmers and Mhlume Water (commercial and smallholder water users), which undertake water management for water users under their jurisdiction. These two institutions handle most of the water management issues on behalf of the users in the lower part of the Komati catchment in Eswatini. On the South African side, the Inkomati-Usuthu Catchment Management Agency (IUCMA) handles water management issues on behalf of the water users, working with specialised water institutions like the irrigation boards. The IUCMA performs water resource management at the local level involving protection, use, development, conservation and control of water resources within the Inkomati-Usuthu Water Management Area. The Komati and Lomati Irrigation Boards are the main irrigation boards in the Komati catchment in South Africa, representing the irrigators.

At transboundary level, the Joint Water Commission (JWC) serves as a technical adviser to the countries on matters relating to the development and utilization of the shared water resources. It is responsible for the overall governance of the Komati Basin; however, if the matter at hand affects Mozambique, then the TPTC deals with the matter. Both the JWC and TPTC are responsible for advising on policy-related matters. KOBWA works with the Komati Joint Operations Forum (KJOF). The KJOF is formed by members of the Komati River Basin Authority, IUCMA, government officials from the DWA/DWS (South African Department of Water and Sanitation) as well as representatives of the water users in both countries. The forum advises KOBWA on the daily operational matters of the Komati River Basin. The Inkomati System Operating Task Group (ISOTG) was formed in 1998 by the TPTC to assist with the development of operating rules for the entire Incomati basin. The responsibility of the ISOTG with regards to the Komati River Basin is to make proposals and advise the TPTC on technical matters. The ISOTG is also responsible for the development of operating rules for Maguga and Driekoppies Dams as well as the system of weirs in the Komati and Lomati rivers. 


\section{SPI and SRI results}
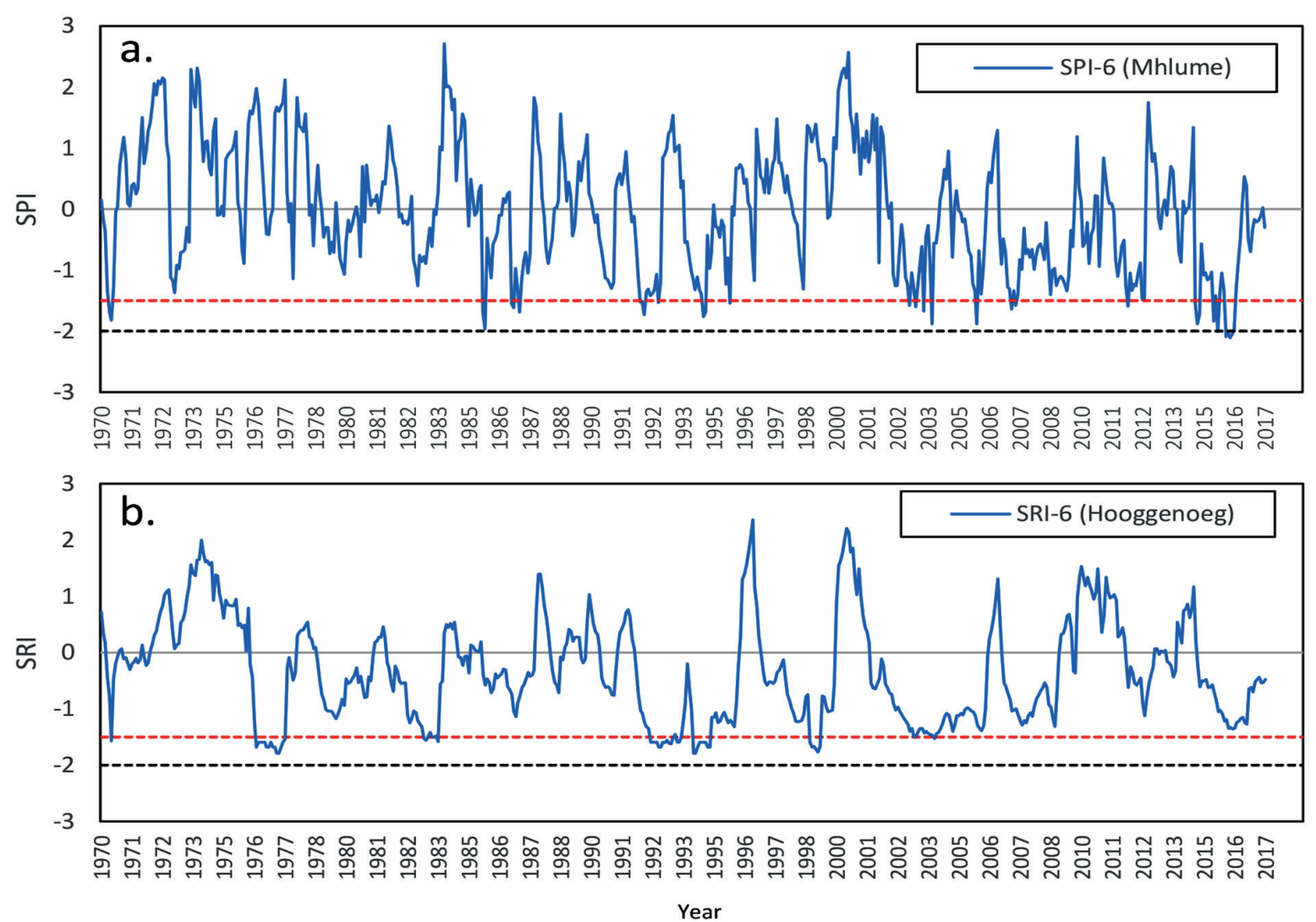

Figure A1. Time series of (a) meteorological drought indicator SPI- 6 at Mhlume, and (b) hydrological drought indicator SRI-6 at Hooggenoeg
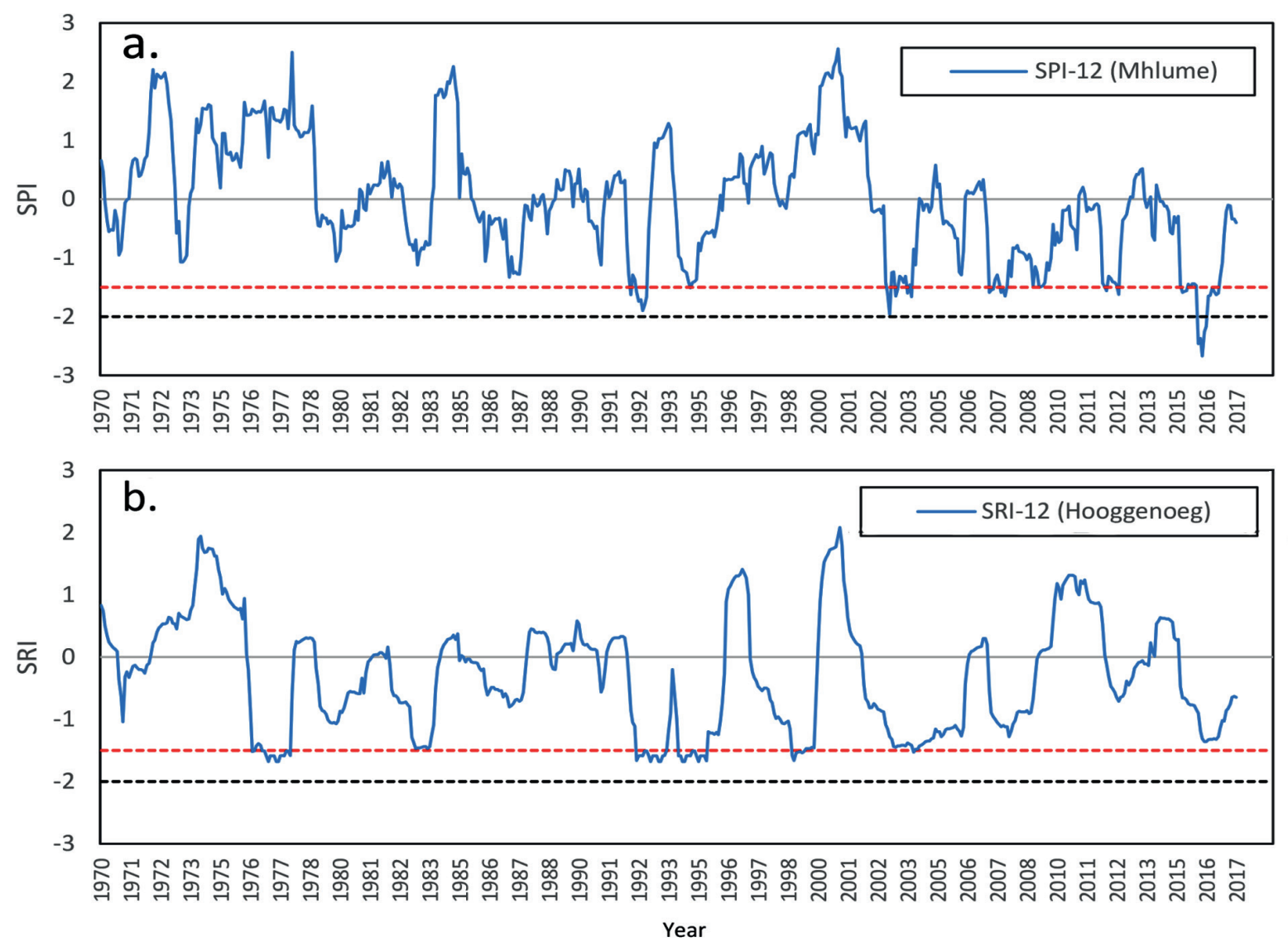

Figure A2. Time series of (a) meteorological drought indicator SPI-12 at Mhlume, and (b) hydrological drought indicator SRI-12 at Hooggenoeg 